\title{
PENINGKATAN KEMAMPUAN BERBICARA BAHASA INGGRIS MELALUI STORYTELLING CERITA RAKYAT KEPADA MAHASISWA ALIYAH PONDOK PESANTREN DARUL MURSYIDI SIALOGO
}

\author{
Nursaima Harahap ${ }^{1)}$, Lisa Fitri Meidifa ${ }^{2)}$, Mahrani ${ }^{3)}$ \\ Program Studi Pendidikan Bahasa Inggris Universitas Graha Nusantara Padangsidimpuan \\ Email : nursaima20okt@gmail.com
}

\begin{tabular}{|l|l|l|}
\hline Dikirim: 25-01-2021 & Direvisi: 20-03-2021 & Diterbitkan: 31-08-2021
\end{tabular}

\begin{abstract}
Abstrak
Story telling atau bercerita merupakan cara pembelajaran yang sudah digunakan sejak zaman dulu dan menjadi alat belajar yang sangat penting. Guru menyampaikan suatu kisah ataupun karya sastra melalui bercerita, dan siswa juga demikian. Morrow menjelaskan bahwa bercerita merupakan kegiatan yang menyenangkan dan merangsang imajinasi siswa. Alasan tim mengambil tema ini selain cerita ini sangat terkenal didaerah sumatera utara khususnya masyarakat mandailing natal dan story telling ini merupakan cara pembelajaran yang sudah digunakan sejak zaman dulu dan menjadi alat belajar yang sangat penting. Guru menyampaikan suatu kisah ataupun karya sastra melalui bercerita, dan siswa juga demikian. Selain itu membuat pembelajaran ini tidak monoton maka guru mengelompokkan peserta didik menjadi beberapa kelompok kemudian guru membagikan teks bahasa inggris yang berisi tentang cerita "sampuraga" kepada masing-masing kelompok dan menyampaikan kepada peserta didik untuk menggaris bawahi kosakata yang mereka ketahui artinya sebanyak 20 kata dalam jangka waktu 15 menit dan guru memantau aktifitas peserta didik. Setelah itu masing-masing kelompok harus menuliskan kosakata beserta artinya tersebut dipapan tulis secara bergantian sehingga siswa mampu memahami isi cerita tentang sampuraga.
\end{abstract}

\section{Kata kunci: story telling, metode, teknologi}

Story telling is a way of learning that has been used since ancient times and has become a very important learning tool. The teacher tells a story or literary work through story telling and the students do too. Morrow explained that story telling is an activity is fun and stimulates the imagination of students. The reason of teams took this theme was very well known in the North Sumatera region, especially the Mandailing Natal community and story telling was a way of learning that has been used since ancient times and has become a very important learning tool. The teacher conveys a story or literacy work through storytelling and the students do likewise. In addition to make this learning not monotonous, the teacher making groping into several groups then teacher shares English text which contains the story of Sampuraga to each group and tells the students to underline what they know the meaning of as many as 20 words in a period of 15 minutes and the teacher monitors students' activities. After that, each group wrote down the vocabulary and meanings on the whiteboard in turn so that the students could understand the contents of the story about sampuraga. 


\section{Keywords : story telling, method, technology}

\section{LATAR BELAKANG}

Keterampilan berbicara adalah suatu kemampuan mengucapkan atau melafalkan sesuatu gagasan yang ada pada diri individu yang melibatkan aspek pelafalan, kosakata, dan struktur. Tujuan dari berbicara adalah untuk mengungkapkan sesuatu gagasan atau perasaan yang ada pada diri individu yang didapat dari hasil menyimak sesuatu materi atau bahan ajar. Salah satu metode yang dapat digunakan untuk meningkatkan kemampuan berbicara siswa adalah metode story telling atau bercerita. Bercerita merupakan kegiatan yang menyenangkan dan merangsang imajinasi siswa. Bercerita dapat mengembangkan kemampuan berbahasa mereka dan membantu mendalami karakteristik dalam cerita serta memperluas pemahaman mereka.

Peningkatan mutu pendidikan adalah kebutuhan bangsa yang ingin maju. Pendidikan yang bermutu dapat menunjang pembangunan di segala bidang. Oleh karena itu, pendidikan perlu mendapat perhatian yang besar agar bangsa Indonesia dapat mengejar ketinggalan di bidang ilmu pengetahuan dan teknologi yang diperlukan untuk mempercepat pembangunan dewasa ini. Pendidikan yang bermutu perlu mendapat perhatian serius dari pemerintah. Dalam proses peningkatan mutu pendidikan, guru memegang peranan penting secara fundamental dengan penanaman nilai-nilai yang baik kepada siswa dalam setiap kegiatan belajar mengajar, karena guru sebagai pendidik selain membimbing siswa dalam kegiatan belajar mengajar, guru juga harus dapat mentransformasikan nilai-nilai yang dapat membentuk watak siswa serta kepribadian yang baik pula. Guru harus mampu mengaplikasikan semua kompetensinya untuk mewujudkan pendidikan yang bermutu dalam semua mata pelajaran termasuk mata pelajaran bahasa Inggris yang dimana sekarang sudah diterapkan diseluruh sekolah-sekolah sebagai bahasa internasional.

Berbicara merupakan keterampilan berbahasa yang dibawah dari rumah. Anak sudah mampu berbicara sebelum mereka mulai belajar membaca dan menulis. Baik siswa maupun guru pasti lebih banyak menggunakan cara komunikasi ini dibandingkan dengan menulis. Tompkins dan Hosskisson (1995:120) mengungkapkan bahwa berbicara merupakan model pengekspresian bahasa yang paling utama. Dewasa ini dalam dunia pendidikan kita terjadi kemerosotan pembelajaran bahasa terutama di lingkup sekolah dasar. Dengan adanya ujian nasional yang mensyaratkan kelulusan siswa melalui ujian tertulis dan berupa soal pilihan ganda, mengakibatkan pembelajaran bahasa terpaku pada peningkatan keterampilan membaca dan menulis. Pembelajaran bahasa yang melibatkan kegiatan menyimak dan berbicara menjadi kurang diperhatikan, bahkan cenderung diabaikan. Padahal keterampilan berbicara sangat penting dalam kehidupan sehari-hari.

Tompkins dan Hosskisson (1995:121) menyampaikan bahwa siswa berbicara untuk memecahkan masalah, menyelesaikan tujuan, atau menghasilkan interpretasi maupun pengetahuan baru dalam percakapan kelompok kecil. Dengan berbicara siswa dapat mencapai tujuan 
pembelajaran untuk memperoleh pengetahuan baru serta dapat meningkatkan kemampuan komunikasi mereka dengan orang lain.

Strickland (2007:164) berpendapat jika tujuan sekolah adalah untuk mendidik, maka sekolah harus menjadi tempat dimana siswa dapat berbicara untuk mengeksplor dan belajar, bukan sekedar mereproduksinya. Oleh sebab itu, guru harus mampu menyediakan kesempatan bagi siswa dalam rangka mengembangkan kemampuan bicara mereka. Kegiatan belajar mengajar saat ini membutuhkan kreativitas guru dalam menggunakan berbagai metode yang menarik dan dapat menumbuhkan peran aktif siswa. Sebisa mungkin siswa diberi aktivitas yang membuat mereka dapat mendapatkan pemahaman yang lebih baik.

Salah satu metode yang dapat digunakan untuk meningkatkan kemampuan berbicara siswa adalah metode storytelling atau bercerita. Cerita merupakan sarana belajar yang baik dan efisien dalam proses kegiatan pembelajaran berbicara bagi anak sekolah. Cerita yang disampaikan dengan baik dan benar dapat menginspirasi suatu tindakan, membantu mengembangkan apresiasi budaya, dan memperluas pengetahuan anak. Cerita juga dapat memberikan kesenangan ketika disampaikan dan didengarkan, membantu anak-anak memahami dunia mereka dan bagaimana mereka berhubungan dengan orang lain (Pratiwi, 2010:171).

Berdasarkan latar belakang, dalam tulisan ini akan dikaji dua permasalahan terkait hal tersebut. Pertama, masalah yang terkait dengan bagaimana meningkatkan kemampuan keterampilan berbicara siswa sekolah dasar. Kedua, permasalahan yang menjawab apakah metode story telling digunakan untuk meningkatkan keterampilan berbicara siswa.

\section{METODE PELAKSANAAN}

Pada pengabdian kepada masyarakat (PKM) ini, dilaksanakan di sialogo Padangsidimpuan tepatnya di pesantren Darul Mursyidi yang menjadi objeknya peserta didik di tingkat MAN/ Aliyah dikelas X (sepuluh). Pemilihan lokasi pengabdian ini dikarenakan proses pembelajaran di Pesantren tetap aktif meskipun dalam masa pandemi Covid 19 tapi sekolah tetap memberlakukan protokol kesehatan sesuai dengan anjuran pemerintah. Perlu diketahui bahwa sesuai dengan himbauan pemerintah bahwa sekolah pendidikan pesantren tetap diperbolehkan pembelajaran tatap muka disekolah karena peserta didik berada tetap di asrama artinya akses peserta didik hanya dilingkungan sekolah. Pelaksanaan pengabdian ini berlangsung selama satu semester yaitu dari bulan Juli-Desember 2020.

Adapun judul pada materi pengabdian ini adalah "Peningkatan kemampuan berbicara bahasa Inggris melalui Story telling cerita rakyat kepada mahasiswa Aliyah Pondok Pesanteren Darul Mursyidi Siaologo". Kegiatan pada pertemuan ini menggunakan metode story telling, story reading dan story comprehension. Guru bercerita sebuah cerita rakyat dengan judul "Sampuraga", yang menceritakan seorang anak yang malu mengakui ibu kandungnya setelah dia menjadi orang sukses dan menikah dengan seorang putri raja, alasan tim mengambil tema ini selain cerita ini 
sangat familiar diketahui oleh orang Sumatera Utara khususnya masyarakat Mandailing Natal dan ini merupakan cara pembelajaran yang sudah digunakan sejak zaman dulu dan menjadi alat belajar yang sangat penting. Guru menyampaikan suatu kisah ataupun karya sastra melalui bercerita, dan siswa juga demikian. Selain itu membuat pembelajaran ini tidak monoton maka guru mengelompokkan peserta didik menjadi beberapa kelompok kemudian guru membagikan teks bahasa inggris yang berisi tentang cerita "sampuraga" kepada masing-masing kelompok dan menyampaikan kepada peserta didik untuk menggarisbawahi kosakata yang mereka ketahui artinya sebanyak 20 kata dalam jangka waktu 15 menit dan guru memantau aktifitas peserta didik. Setelah itu masing-masing kelompok harus menuliskan kosakata tersebut dipapan tulis secara bergantian. sehingga siswa mampu memahami isi cerita tentang sampuraga. Kemudian guru menyampaikan kepada siswa untuk mencari cerita rakyat dalam teks bahasa inggris dan menceritakannya didepan kelas.

Dari metode ini siswa lebih bersemangat untuk mengerjakannya dan tidak ada perasaan minder karena mereka bisa diskusikan bersama dengan teman kelompok mereka, setelah itu guru menanyakan kelompok yang dapat menerjermahkan teks secara per paragraph, bagi kelompok yang dapat menerjemahkan lebih banyak akan menjadi pemenang dalam proses pembelajaran ini dan guru memberikan hadiah buat kelompok yang menang dan hukuman hiburan bagi kelompok yang kalah.

Morrow menjelaskan bahwa bercerita merupakan kegiatan yang menyenangkan dan merangsang imajinasi siswa. Bercerita dapat mengembangkan kemampuan berbahasa mereka dan membantu mendalami karakteristik dalam cerita serta memperluas pemahaman mereka. Roney (Isbell et al., 2004) menjelaskan bahwa di dalam story telling aspek yang harus diperhatikan agar berjalan dengan efektif adalah mencoba kreatif dan memiliki komunikasi dua arah (story teller dan pendengar). Selain itu, kontak mata dengan pendengarpun sangat penting untuk diperhatikan, jika anak melihat kontak mata story teller, mereka saling melakukan tatapan dalam interaksi, pada akhirnya akan membuat pengalaman menjadi lebih personal dari pada story teller hanya membaca buku cerita (Isbell et al., 2004). Story telling yang digunakan untuk meningkatkan kecerdasan anak juga harus disesuaikan dengan level kognitif anak. 


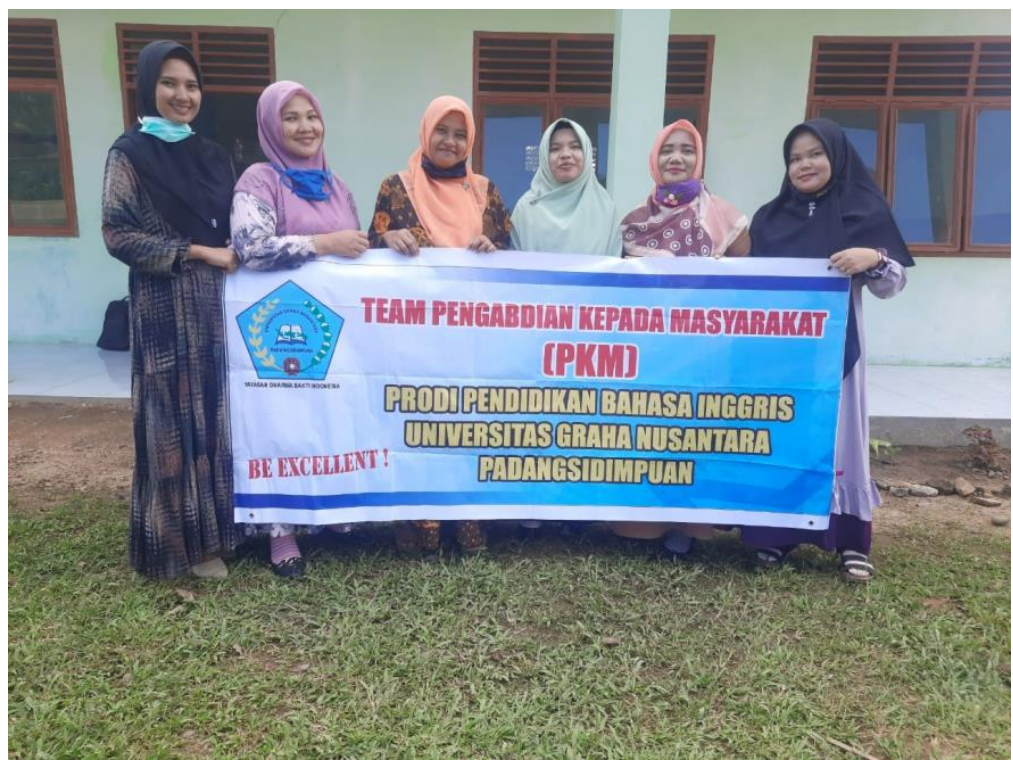

Gambar 1. Foto bersama dengan ibu kepala sekolah

\section{HASIL DAN PEMBAHASAN}

Kegiatan Pengabdian Kepada Masyarakat dilaksanakan di Madrasah Aliyah Pondok Pesantren Darul Mursyidi Sialogo Padangsidimpuan selama satu semester mulai dari bulan Juli sampai dengan Desember 2020. Hal pertama yang dilakukan tim sebelum terjun kelapangan adalah menghubungi pihak sekolah melalui sambungan telepon berhubung karena masih dalam kondisi covid 19. Setelah menunggu beberapa hari akhirnya kepala sekolah memberikan izin untuk melaksanakan pengabdian ke pesantren tersebut dengan catatan tetap mematuhi protokol kesehatan. Selanjutnya tim pengabdian terjun ke lapangan untuk monitoring keadaan dan situasi di pesantren tersebut, kepala sekolah sangat menyambut baik kedatangan tim pengabdian berhubung karena bahasa inggris belum menjadi mata pelajaran prioritas disekolah tersebut tapi mata pelajaran wajib mereka adalah bahasa arab dan tahfiz qur'an sehingga pihak sekolah sangat antusias dengan kegiatan ini.

Pada pertemuan berikutnya di bulan agustus tim langsung ke sekolah untuk melaksanakan pengadian di Madrasah Aliyah Pondok Pesantren Darul Mursyidi Sialogo Padangsidimpuan. Kegiatan pengadian ini sangat disambut antusias oleh guru dan siswa disekolah tersebut. Sebelum memulai kegiatan tim terlebih dahulu datang temu ramah dengan para siswa menyampaikan maksud dan tujuan tim pengabdian datang ke sekolah tersebut. Berhubung karena tempat pengabdian tersebut merupakan sekolah pesantren jadi siswa laki-laki dan perempuan duduk terpisah dengan dibatasi oleh tirai. Tapi hal ini tidak menyurutkan semangat dan antusias siswa untuk belajar bahasa inggris.

Salah satu alasan mengapa tim memilih metode story telling adalah dapat membantu mengajari siswa untuk mendengar, membantu membangun keterampilan komunikasi oral dan 
tulisan, dan mengembangkan pemahaman dari cerita skema. Farrel dan Nessell (Isbell et al., 2004) menjelaskan bahwa story telling membantu mengembangkan kelancaran, menambah perbendaharaan kata, dan membantu mengingat kata. Selain itu, Marrow menyakini bahwa story telling adalah salah satu cara untuk mengembangkan bahasa di kelas. Oleh karena itu, untuk meningkatkan keterampilan berbicara dapat menggunakan metode story telling atau bercerita.

Tompkins dan Hosskisson (1995:129 131) menyampaikan empat langkah dalam bercerita dalam kaitannya untuk meningkatkan keterampilan berbicara. Seperti penjelasan berikut.

1. Pemilihan cerita Cerita tradisional atau cerita rakyat biasanya yang dipilih untuk kegiatan bercerita, namun tidak menutup kemungkinan memilih literatur lain yang sesuai. Pertimbangan utama dalam pemilihan cerita adalah memilih cerita yang disukai, dikenali dan mudah disampaikan.

Tim memberikan materi beberapa hal yang harus di pertimbangan dalam pemilihan cerita yakni:
a. ceritanya sederhana, memiliki plot yang runtut,
b. awal, pertengahan dan akhir ceritanya jelas,
c. memiliki tema yang mudah dipahami,
d. karakter/ tokoh yang disampaikan tidak terlalu banyak,
e. mengandung dialog,
f. menggunakan perulangan, dan
g. memakai bahasa yang mudah ditangkap anak.

2. Persiapan bercerita

Siswa merencanakan dan melatih ceritanya sebelum menampilkannya. Mereka tidak harus menghafalkannya supaya dapat bercerita secara efektif. Lebih baik mereka memilih sendiri cerita yang sudah diketahui, lalu dibaca lagi untuk membuat mereka lebih memahami karakter dan peristiwa penting dalam urutan yang runtut. Siswa juga dapat memilih bagian mana yang menarik dalam cerita untuk diberi penekanan, pengulangan atau bahkan dengan suara-suara yang berbeda dalam rangka membuat cerita yang disampaikan lebih menarik dan berkesan bagi pendengar. Siswa juga harus menyiapkan pengantar yang baik untuk memperkenalkan cerita sebelum memulai kegiatan bercerita itu sendiri.

3. Menambahkan properti/alat peraga Siswa dapat menggunakan beberapa teknik untuk membuat ceritanya lebih hidup, salah satunya menggunakan alat peraga atau properti. Beberapa alat peraga yang digunakan seperti gambar yang ditempelkan di papan flannel, boneka atau wayang, atau objek yang menonjol dalam ceritanya misalnya seperti topi, bola, kotak, dan sebagainya.

4. Bercerita

Siswa menyampaikan cerita yang sudah disiapkan kepada teman satu kelas atau dapat juga guru membagi kelas menjadi beberapa kelompok kecil supaya dapat lebih banyak siswa yang bercerita dalam satu waktu. 


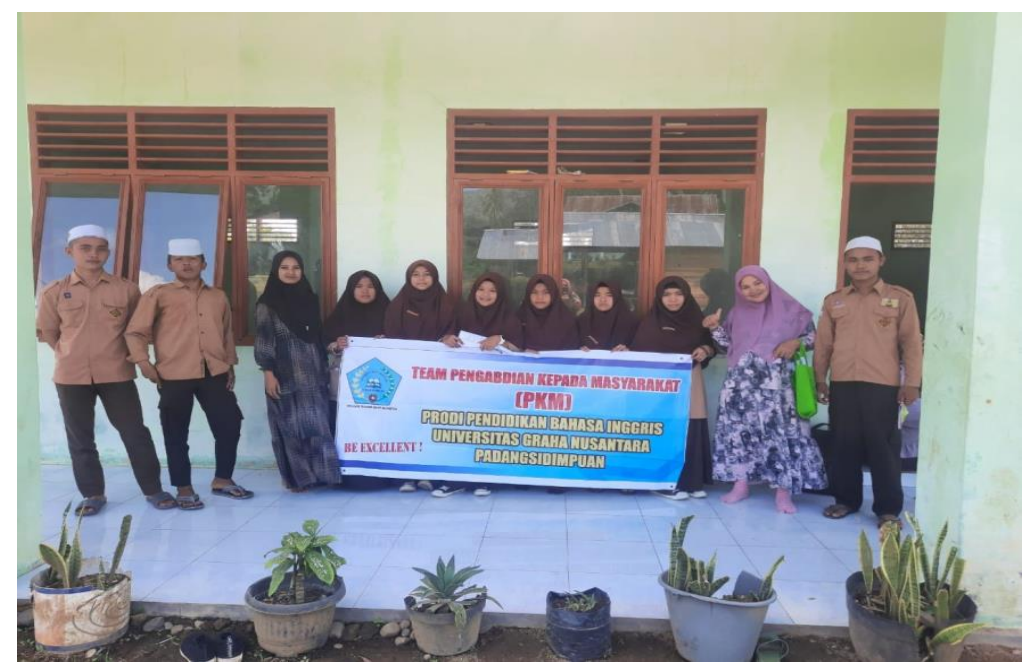

\section{Gambar 2. Foto bersama dengan siswa pesantren darul mursyidi}

Adapun pertemuan dengan siswa dilaksanakan sebanyak 8 kali pertemuan, hal ini dilakukan karena covid 19 dan atas saran dari kepala sekolah tersebut. Tim pengabdian dan sekolah juga tidak lupa untuk selalu melakukan protokol kesehatan. Sebelum masuk kelas tim pengabdian selalu cuci tangan dan menggunakan masker. Pada pertemuan pertama sampai ketiga tim memberikan penjelasan tentang teknik membaca/story telling. Selanjutnya pada pertemuan keempat tim menerapakan metode story telling dengan menyiapkan cerita rakyat yaitu "sampuraga".

Pada awalnya siswa masih banyak yang malu untuk berbicara bahkan sebagian tidak mau disuruh bercerita dikelas, jadi tim melakukan pendekatan yang persuasif dan meyakinkan siswa bahwa belajar bahasa inggris itu mudah dan menyenangkan akhirnya siswa semakin lama semakin antusias untuk mendengar cerita rakyat dari tim dan begitu juga sebaliknya dan diakhir pembelajaran tim menanyakan hikmah yang terkandung didalam cerita dan siswa dengan sangat semangat menjawab pertanyaan dari tim.

Langkah-langkah diatas merupakan kegiatan yang dilakukan oleh tim pengabdian sampai pertemuan selesai pada bulan November. Pada bulan desember sebelum kegiatan PKM selesai tim pengabdian hanya melakukan review terhadap pelajaran yang sudah diberikan dan memberikan pendalaman materi yang belum siswa mengerti. Metode story telling tersebut sangat menarik minat belajar dan percaya diri siswa untuk bercerita tentang cerrita rakyat yang mereka ketahui dan tim melihat perubahan yang significant adalah pengucapan dan meningkatnya kosakata siswa.

\section{KESIMPULAN}

Belajar bahasa Inggris maupun bahasa Indonesia dengan metode bercerita berpengaruh positif baik bagi siswa maupun guru. Siswa dapat belajar berekspresi, belajar berani tampil di depan umum, dan tentu saja perkembangan kognitif siswa sangat terbantu. Selain itu, bagi guru penerapan metode bercerita ini merupakan salah satu bentuk pembelajaran siswa aktif dan 
pengamatan langsung guru terhadap kemampuan siswa. Hal yang perlu ditekankan adalah bahwa pembelajaran apa saja dapat diselenggarakan dengan media cerita. Pembiasaan siswa bercerita dapat digunakan untuk melatih keterampilan berbicara siswa. Selain itu, bercerita/berbicara menjadi kebutuhan yang penting bagi pembentukan mental siswa. Dalam pembelajaran sistem terpadu bahan ajar yang diberikan erat hubungannya dengan kehidupan sehari-hari. Guru dapat menambahkan bahan ajar sesuai dengan perkembangan zaman, kondisi lingkungan sekolah, dan kondisi siswa itu sendiri.

\section{UCAPAN TERIMA KASIH}

Akhirnya tim banyak mengucap syukur kepada Allah dan terima kasih yang sebesarbesarnya buat pihak terkait dalam hal ini pihak yayasan, para guru, staf dan siswa-siswi Pesantren Darul Mursyidi Sialogo yang terlibat dalam kegiatan ini akhirnya kegiatan ini terlaksana dengan sukses dan lancar tanpa hambatan yang berarti dan ungkapan bahagia kami dari tim pengabdian kerena telah diterima dengan baik oleh pihak sekolah khususnya ibu kepala Sekolah yang setia mendampingi tim dalam menyelesaikan pengabdian hingga tuntas serta semangat siswa dalam mengikuti pembelajaran hingga selesai, semoga kerja sama ini terjalin dikesempatan berikutnya.

\section{DAFTAR PUSTAKA}

Isbell,R., Sobol, J., Lindauer, L \& Lowrance, A. 2004. The Effects of Storytelling and Story Reading on the OralLanguage Complexity and Story Comprehensionof Young Children. Early Childhood Education Journal, 32(3), December 2004.

Nurgiyantoro, Burhan. 2007. Penilaian dalam Pengajaran Bahasa dan Sastra. Yogyakarta: BPFE. Pamungkas, Sri. 2012. Bahasa Indonesia dalam Berbagai Perspektif. Yogyakarta: Andi Offset. Pratiwi, Dwi. 2010. Peningkatan Keterampilan Berbicara Bahasa Indonesia dengan Kegiatan

Bercerita, Sebuah Alternatif untuk Siswa Sekolah Dasar. Seminar dan Lokakarya Nasional:Penelitian Tindakan Kelas dalam Perspektif Etnografi Program Magister Liguistik Undip, 2 Oktober 2010: 170-187.

Santosa, Puji. 2009. Materi dan Pembelajaran Bahasa Indonesia. Jakarta:Universitas Terbuka. Santrock, John W. 2007. Psikologi Pendidikan. Jakarta: Kencana Prenada Media Group.

Sarwiji Suwandi. 2009. Assesmen Dalam Pembelajaran. Surakarta: Mata Padi Presindo.

Slamet, St. Y. 2007. Dasar-dasar Pembelajaran Bahasa dan Sastra Indonesia Di Sekolah Dasar. Surakarta: LPP dan UNS Press.

Strickland, Dorothy S., Galda, L., \& Cullinan, Bernice E. 2007. Language Arts: Learning and Teaching. Thompson Wadsworth.

Tarigan, Henry Guntur. 1993. Berbicara. Bandung : Angkasa.Tompkins, Gail E. \& Hoskisson, Kenneth. 1995. Language Arts: Content and Teaching Strategies. New Jersey: Prentince Hall. Wright, C., Bacigalupa, C,. Black, T,. Burton, M. 2008. Window into Children Thingking: A Guide to Storytelling and Dramatization. Early Childhood Education J, 35: 363-36 